\title{
An intervention program to enhance social and emotional competencies in pre-service early childhood education teachers
}

\author{
Izabela ZYCH \& Vicente J. LLORENT
}

Universidad de Córdoba, Spain

(Received on Mach 28, 2019; Accepted on October 9, 2019)

\begin{abstract}
Early childhood is a crucial period for the development of social and emotional competencies. Researchers point out that teachers need to have a high level of social and emotional competencies to enhance these competencies in their students but the number of programs to promote these competencies in pre-service teachers is small. The objective of this study was to design, conduct and evaluate an intervention to promote social and emotional competencies in pre-service early childhood education teachers. The study used a non-randomized pre-test, post-test intervention-control design. The intervention included competencies such as emotional awareness and understanding, emotional management, social competence and responsible decision making. Results showed that the level of social and emotional competencies increased after the program, although statistically significant differences between the intervention and control group were found only in some dimensions. It is recommended to include similar programs in pre-service and in-service teacher education in general.
\end{abstract}

Keywords: Social and emotional learning, pre-service teacher education, early childhood education, intervention

\section{Un programa de intervención para mejorar las competencias sociales y emocionales de maestros de educación infantil en formación}

RESUMEN: La primera infancia es un período crucial para el desarrollo de las competencias sociales y emocionales. Los investigadores señalan que los profesores necesitan tener un alto nivel de competencias sociales y emocionales para mejorar estas competencias en sus estudiantes, pero el número de programas para promover estas competencias en los profesores en formación es escaso. El objetivo de este estudio fue diseñar, conducir y evaluar una intervención para promover las competencias sociales y emocionales de los maestros de educación preescolar. El estudio utilizó un diseño de control de intervención no aleatorio antes y después de la prueba. La intervención incluyó competencias como la conciencia y la comprensión emocional, el manejo emocional, la competencia social y la toma de decisiones responsables. Los resultados mostraron que el nivel de competencias sociales y emocionales aumentó después del programa, aunque sólo se encontraron diferencias estadísticamente significativas entre el grupo de intervención y el de control en algunas dimensiones. Se recomienda incluir programas similares en la formación inicial y continua de los docentes en general.

Palabras clave: Aprendizaje social y emocional, formación docente, educación infantil, intervención 
Correspondencia: Izabela Zych (corresponding author), Universidad de Córdoba, Deparment of Psychology, Avda. San Alberto Magno s/n. 14004. Córdoba (Spain). Tel. +34 957218412. E-mail: izych@uco.es

Vicente J. Llorent, Universidad de Córdoba, Deparment of Education, Avda. San Alberto Magno s/n. 14004. Córdoba (Spain). Tel. +34 957218525. E-mail: vjllorent@uco.es

\section{Introducción}

Traditional schools were places where teachers were focused on academic skills only. New approach includes also skills for life such as competencies to live in a society, work in teams, manage emotions, initiate and maintain positive interpersonal relationships and embrace diversity. (Haymovitz, Houseal-Allport, Lee, \& Svistova, 2017; Poulou, 2017a). This approach is very important in early childhood education where children enter a formal education setting for the first time, are educated for school readiness and acquire basic social and emotional competencies (Darling-Churcill \& Lippman, 2016; Royal Decree 1630/2006). At this stage of development, children learn how to regulate emotions, improve understanding and communication of emotions and acquire knowledge about emotions of others (Jones \& Doolittle, 2017). Pons, Harris and de Rosnay (2004) pointed out that when children are about five years old, they learn to understand the causes of different emotions, how the context affects emotions and how emotions are publically expressed. Social and emotional development is full of challenges (Mahoney, Durlak, \& Weissberg, 2018) and early childhood education schools are places where children express their emotions in activities such as playing, assembly, tasks or dismissal (Zych, Sibaja, \& Ortega, 2016). It is also a setting where interactions among peers take place for the very first time (Ortega, Romera, Mérida, \& Monks, 2009).

High-quality preschool programs can provide a perfect setting for the development of these competencies (Parker, Hogan Eastabrook, Oke, \& Wood, 2006; Schweinhart, Montie, Xiang, Barnett, Beldfield, \& Nores, 2005; Yang, Datu, Lin, Lau, \& Li, 2019). Research showed that some developmental interventions conducted in early childhood education can even prevent delinquency later in life (see a review of programs by Zych, \& Farrington, 2018). Among them, for example, Perry Preschool Program which was a curriculum based approach implemented with 3 and 4 years old children showed that, after a 40-year follow-up (Schweinhart et al., 2005) the intervention group had lower numbers of lifetime arrests in adolescence and lower percentage of people ever sentenced to jail at age 40, among other benefits.

A meta-analysis of more than 200 school-based universal programs conducted in different educational levels showed that, overall, these interventions effectively improved students' skills, attitudes and behaviors (Durlak, Weissberg, Dymnicki, Taylor, \& Schellinger, 2011). Many of these programs were based on the Social and Emotional Learning (SEL) approach (Elbertson, Brackett, \& Weissberg, 2009). Social and emotional learning was defined as learning social and emotional competencies which consist of understanding, managing and expressing social and emotional content. Social and emotional learning aims at helping in different life tasks such as adapting to life demands, initiating or maintaining relationships, or problem solving (Taylor, Oberle, Durlak, \& Weissberg, 2017; Van Ryzin \& Roseth, 2018). 
A comparison of programs included in the meta-analysis reported by Durlak et al. (2011) shows that programs conducted by school personnel were more effective than interventions conducted by non-school personnel. Poulou (2017b) concluded that a high level of teachers' social and emotional competencies would be crucial to create a prosocial classroom with good teacherstudent relationships, classroom management and climate. Moreover, Jennings and Greenberg (2009) suggested that successful SEL programs implementation and enhancing students' social and emotional competencies would only be possible if the teachers' level of social and emotional competencies is high. In a longitudinal study, Hamre and Pianta (2001) found that teacher-child relationships in early childhood education predicted academic and behavioral outcomes of the children throughout the following eight years.

Given that early childhood is a crucial period for the development of social and emotional competencies and that teachers are important actors in promoting these competencies, it is reasonable to enhance social and emotional competencies in teachers and future teachers. (Domitrovich et al., 2016, Poulou, 2017b). Cabello, Ruiz-Aranda and Fernández-Berrocal (2010) conducted a narrative review of programs to enhance social and emotional competencies and found only some interventions aimed specifically at teachers. Among them, a US program (Domitrovich et al., 2016, Poulou, 2017b) effective in increasing social and emotional competencies in teachers. Another narrative review conducted by Palomera, Fernández-Berrocal and Brackett (2008) concluded that it was very important to include social and emotional competencies in pre-service teacher training. Moreover, they concluded that these competencies were mentioned in many official documents regarding teacher-education curriculum and yet they were rarely explicitly included in the training itself.

Given the importance of social and emotional competencies in early childhood education teachers and pupils (Jennings et al., 2017), and important gaps in knowledge, it is still necessary to discover how social and emotional competencies can be enhanced in teachers (Domitrovich et al., 2016; Schonert-Reichl, 2017). Thus, the current study was a curriculum-embedded intervention program designed and implemented with the objective of enhancing social and emotional competencies in future early childhood education teachers. This program was included in their regular university training.

\section{Method}

\section{Participants}

The current project was conducted with 126 students of the Degree in Early Childhood Education from a University in Spain, 94 in the intervention group and 32 in the control group. The students in the intervention group were enrolled in the second year of the undergraduate studies, their mean age at pre-test was 20.94 years $(S D=3.05)$ and 21.36 years at post-test $(S D=3.78)$. Among these students, 92.6\% were girls, which is a usual percentage in this degree and profession in general in Spain. It is worth mentioning that the initial sample included 107 participants but 13 of them were absent during the post-test (attrition rate of 12.15\%). The control group was formed by 32 students enrolled in the fourth year of the degree. Their mean age at pre-test was $22.06(S D=2.59)$ and at post-test was $22.30(S D=2.68)$. In the control 
group, 96.9\% were girls. The initial sample included two more students $(\mathrm{n}=34)$ but they were absent during the post-test (attrition rate of 5.88\%).

\section{Procedure}

This study was conducted with a pre-test post-test quasi-experimental design with an intervention and a control group. The intervention program was designed by the authors of the current study based on scientific literature on Social and Emotional Learning. Students were assigned by convenience to intervention (two groups taught by the first author) or control (a group taught by the second author) conditions. In the intervention group, the program was embedded in the regular curriculum within a compulsory course School-wide Climate and Culture of Peace in Early Childhood Education (Convivencia Escolar y Cultura de Paz en Educación Infantil). This course is taught in Grade 2 of the Degree in Early Childhood Education at the University with a main goal of increasing future teachers' knowledge and skills to manage a positive school-wide climate. The control group followed their regular curriculum.

\section{Intervention program}

This intervention was structured in 10 weekly lessons (1.5 hours each) with a total of 15 hours. Participants worked in big (classroom) and small teams of 3-5 students (there were around 15-25 students in each classroom and therefore, there were between 3 and 6 small teams). Each lesson had a different group leader so that each student acted as a leader 2 to 3 times.

At the beginning of each lesson, homework was reviewed by each team and the team leader took notes of the most important points (including similarities and differences among the team members, interesting examples, positive aspects and suggestions on how to improve future behaviors). Leaders of each small group explained the notes to the rest of the students in each classroom (big group) and feedback was provided by the teacher and the rest of the classmates. It was always highlighted that personal examples that students did not will to share should be disclosed at any stage (including the small groups and the classroom work).

In the next step, the teacher explained the new lessons and groups worked on different cases and examples (see annex). These examples were again shared with the rest of the classmates by the team leader or through role-playings. Feedback was given and then, the written example was uploaded by the leader to Moodle (an online learning management system) within one week. Homework that consisted of working on each competence in real-life situations throughout the week was assigned and reviewed in the next lesson.

\section{Instruments}

- Trait Meta-Mood Scale (TMMS-24) (Salovey, Mayer, Goleman, Turvei, \& Palafai, 1995), in its Spanish version (Fernández-Berrocal, Extremera, \& Ramos, 2004) was used to measure perceived emotional intelligence. The scale contains 24 items divided into three factors: emotional attention ( 8 items), emotional clarity ( 8 items) and emotional repair (8 items) answered on a 5-point Likert scale ranging from 1 (strongly disagree) to 5 (strongly agree). Spanish version of the scale shows excellent 
Cronbach's alphas $(\alpha=.90-$ emotional attention; $\alpha=.90$ - emotional clarity and $\alpha=$ .86 - emotional repair).

- Social and Emotional Competencies Questionnaire (SEC-Q) (Zych, Ortega-Ruiz, Muñoz-Morales, \& Llorent, 2018) with 17 items answered on a 5-point Likert scale ranging from 1 (strongly disagree) to 5 (strongly agree) was used to measure four social and emotional competencies (subscales) - Self-awareness $(\Omega=.83, \alpha=.83$ ), self-management $(\Omega=.81, \alpha=.79)$, social-awareness and prosocial behavior $(\Omega=.78$, $\alpha=.77)$ and decision making $(\Omega=.77, \alpha=.75)$ (total $\Omega=.87, \alpha=.87$ ).

\section{Data analysis}

Paired t-tests were conducted to find possible differences between pre-test and post-test scores in the intervention and in the control group. Independent group t-tests were performed to compare the pre-test scores between the intervention and the control group. After checking the assumptions, ANCOVA analyses were performed with intervention vs. control group as a fixed factor, post-test scores as dependent variables and pre-test scores as covariates to find possible change after the intervention. ANCOVA is an analysis that incorporates both, regression and comparison of means. This analysis was chosen because it minimizes the impact of the baseline scores on the outcome and has greater statistical power when compared to ANOVA (Baguley, 2012). These analyses were conducted with SPSS software and were conducted separately for the whole sample and also for the participants who scored below percentile 50 in the pre-test perceived emotional intelligence and social and emotional competencies, respectively. An overall effect size (odds ratios and confidence intervals) was calculated with the formulas used by Farrington and Ttofi (2009) in their meta-analysis of anti-bullying interventions. This was done to check if the overall effect size of this program was significant. Odds ratios above 1 indicate desirable change whereas odds ratios below 1 indicate undesirable change. Confidence intervals that include 1 indicate that the effect is not statistically significant.

\section{Results}

\section{Improvement in social and emotional competencies}

A comparison of the post-test mean scores of the intervention vs. control group in perceived emotional intelligence and social and emotional competencies, using the pre-test scores as covariates (ANCOVA), showed that there was a significant difference in post-test emotional clarity. Differences between the intervention vs control group in other variables were not significant (see table 1). An overall effect including all the subscales was not significant (OR = $1.06,95 \% \mathrm{CI}=.51-2.20)$. 
Table 1. Means and standard deviations in total pre and post-test scores and subscales of perceived emotional intelligence and social and emotional competencies for the intervention $(n=90)$ and control $(n=32)$ group

\begin{tabular}{|c|c|c|c|c|c|c|c|c|}
\hline & \multicolumn{3}{|c|}{ Intervention } & \multicolumn{3}{|c|}{ Control } & \multirow[b]{2}{*}{$\begin{array}{l}\text { Pre-test } \\
\text { (intervention vs. } \\
\text { control) } t_{(121)}\end{array}$} & \multirow[b]{2}{*}{ ANCOVA } \\
\hline & $\begin{array}{l}\text { Pre-test } \\
M(S D)\end{array}$ & $\begin{array}{l}\text { Post-test } \\
M(S D)\end{array}$ & $t_{(89)}$ & $\begin{array}{l}\text { Pre-test } \\
M(S D)\end{array}$ & $\begin{array}{l}\text { Post-test } \\
M(S D)\end{array}$ & $t_{(31)}$ & & \\
\hline Emotional attention & $26.9(6.53)$ & $27.93(5.73)$ & 1.94 & $25.19(6)$ & $26.77(6.8)$ & $2.35^{*}$ & 1.33 & .001 \\
\hline Emotional clarity & $26.61(6.05)$ & $28.65(5.78)$ & $4.22 *$ & $24.73(9.91)$ & $25.27(6.72)$ & .71 & 1.44 & $5.203^{*}$ \\
\hline Emotional repair & $24.70(6.17)$ & $26.97(6.65)$ & $3.62^{*}$ & $26.37(6.11)$ & $27.23(7.08)$ & 1.18 & 1.03 & .668 \\
\hline $\begin{array}{l}\text { Total perceived emotional } \\
\text { intelligence }\end{array}$ & $77.82(13.47)$ & $83.39(13.43)$ & $4.82 *$ & $76.92(13.43)$ & $80.04(14.96)$ & 1.89 & .47 & 1.657 \\
\hline Self-awareness & $15.17(2.05)$ & 15.59 (2.48) & 1.69 & $14.16(2.34)$ & $15.16(2.25)$ & 1.13 & 1.04 & .172 \\
\hline Self-management & $11.97(2.04)$ & $12.27(1.95)$ & 1.30 & $11.42(1.89)$ & $11.71(1.74)$ & 1.16 & 1.14 & .841 \\
\hline $\begin{array}{l}\text { Social -awareness and } \\
\text { prosocial behavior }\end{array}$ & $24.15(2.28)$ & $24.60(2.74)$ & 1.69 & $24.23(2.34)$ & $24.53(2.39)$ & .72 & .00 & .056 \\
\hline Decision making & $11(2.32)$ & $11.47(2.41)$ & 1.88 & $10.56(2.20)$ & $11.06(2.50)$ & 1.53 & .93 & .137 \\
\hline $\begin{array}{l}\text { Total social and emotional } \\
\text { competencies }\end{array}$ & $62.48(5.94)$ & 63.99 (7.24) & $2.21^{*}$ & $61.68(5.75)$ & $63(5.84)$ & 1.58 & 1.15 & .132 \\
\hline
\end{tabular}

$* p<.05$

\section{Improvement in social and emotional competencies in participants with low pre-test scores}

The total score in perceived emotional intelligence in the pre-test was divided into percentiles. The percentile 25 was 68.25 , percentile 50 was 80 and percentile 75 was 88 . Later, participants with scores above percentile 50 were excluded and scores were compared among the participants below percentile 50 (experimental $n=43$, control $n=14$ ). For these participants, differences between the intervention versus control groups were found in post-test emotional repair and selfmanagement. There was no significant change in other subscales (see table 2). An overall between group pre-post effect including all the subscales showed desirable change but was it not statistically significant $\mathrm{OR}=1.49(95 \% \mathrm{CI}=.53-4.16)$.

Table 2. Means and standard deviations in in total pre and post-test scores and subscales of perceived emotional intelligence and social and emotional competencies, in participants below the percentile 50, for the intervention and control groups.

\begin{tabular}{|c|c|c|c|c|c|c|c|c|}
\hline & $\begin{array}{c}\text { Pre-test } \\
M(S D)\end{array}$ & $\begin{array}{c}\text { Intervention } \\
\text { Post-test } \\
M(S D)\end{array}$ & $\begin{array}{l}t \text { (42-emotional } \\
\text { intelligence); }(41 \\
\text { - social and } \\
\text { emotional } \\
\text { competencies) }\end{array}$ & $\begin{array}{c}\text { Pre-test } \\
M(S D)\end{array}$ & $\begin{array}{c}\text { Control } \\
\text { Post-test } \\
M(S D)\end{array}$ & $\begin{array}{c}t \text { (13 - emotional } \\
\text { intelligence); (18 - } \\
\text { social and } \\
\text { emotional } \\
\text { competencies) }\end{array}$ & $\begin{array}{c}\text { Pre-test } \\
\text { (intervention } \\
\text { vs. control) } \\
t(55)\end{array}$ & $A N C O V A$ \\
\hline Attention & $23.56(6.42)$ & $25.91(5.69)$ & $3.04 *$ & $22.07(6.21)$ & $24(7.18)$ & 2.16 & .75 & .002 \\
\hline Clarity & $22.93(5.11)$ & $25.44(4.81)$ & $3.06^{*}$ & $20.57(5.21)$ & $22.43(6.10)$ & 1.61 & 1.49 & .357 \\
\hline Repair & $20.67(3.72)$ & $24.60(5.56)$ & $5.86^{*}$ & $23.29(4.91)$ & $24.43(6.19)$ & 1.07 & $2.11 *$ & $8.162 *$ \\
\hline $\begin{array}{l}\text { Total perceived } \\
\text { emotional } \\
\text { intelligence }\end{array}$ & $67.16(8.76)$ & $75.95(10.01)$ & $5.55^{*}$ & $65.93(8.63)$ & $70.79(11.89)$ & 2.05 & .46 & .098 \\
\hline Self-awareness & $14.08(2.36)$ & $14.84(2.36)$ & 1.71 & $13.21(2.58)$ & $14.28(1.44)$ & 1.92 & 1.17 & .24 \\
\hline Self-management & $10.54(1.73)$ & $11.89(1.72)$ & $4.10^{*}$ & $10.33(1.72)$ & $10.87(1.60)$ & 1.47 & .39 & $3.88^{*}$ \\
\hline
\end{tabular}


Intervention in Early Childhood Education Teachers in Training

\begin{tabular}{|c|c|c|c|c|c|c|c|c|}
\hline $\begin{array}{l}\text { Social-awareness } \\
\text { and prosocial } \\
\text { behavior }\end{array}$ & $22.82(1.89)$ & $24.18(2.50)$ & $4.03 *$ & $23.22(1.77)$ & $23.61(1.65)$ & .81 & .40 & 2.07 \\
\hline Decision making & $10.05(2.46)$ & $10.86(2.78)$ & 1.96 & $9.47(2)$ & $10.73(2.81)$ & $2.74 *$ & .82 & .17 \\
\hline $\begin{array}{l}\text { Total social and } \\
\text { emotional } \\
\text { competencies }\end{array}$ & $57.23(2.90)$ & $61.46(5.88)$ & $4.96^{*}$ & $58.06(2.56)$ & $61.00(5.01)$ & $2.80^{*}$ & 1.03 & .015 \\
\hline
\end{tabular}

$* p<.05$

\section{Discussion}

Early childhood is a crucial period for the development of social and emotional competencies (Denham, 2007; Yang et al., 2019). Some programs designed and conducted to enhance social and emotional competencies in early childhood had a desirable long-term effect on different areas (Haymovitz, Houseal-Allport, Lee, \& Svistova, 2017; Poulou, 2017) and also on antisocial behavior and delinquency (Schweinhart et al., 2005). Programs conducted by teachers are more effective than programs conducted by non-school personnel (Durlak et al., 2011) and research reviews suggested that teachers need to have a high level of social and emotional competencies to be able to conduct these programs with pupils (Jennings \& Greenberg, 2009). Nevertheless, the number of programs to enhance social and emotional competencies in teachers and future teachers is low (Cabello et al., 2010; Conners-Burrow et al., 2017; Palomera et al., 2008). This study aimed at filling this gap in knowledge and consisted of a curriculum-embedded intervention program designed and implemented to enhance social and emotional competencies in future early childhood education teachers.

This intervention program was inspired on Social and Emotional Learning approach (Elbertson et al., 2009). It included ten lessons that focused on emotional awareness and understanding, emotional management, self-esteem, empathy, assertiveness and responsible decision making. These lessons were taught in an active and interactive way, including group work, practical examples and role-playing. When compared to the control group, this program improved emotional clarity in the intervention group. In participants with a low baseline level of social and emotional competencies, improvement was found in emotional repair and self-management.

Results of this study showed improvement in all the social and emotional competencies in the intervention group, although only some of the results reached statistical significance when compared to controls. Specifically, for the whole sample, emotional clarity improved after the intervention and for students with low baseline level of social and emotional competencies statistically significant differences were found in emotional repair and self-management and motivation. Other competencies improved, but there was no statistically significant difference when compared to controls. This could possibly be explained by the fact that social and emotional competencies improved also in the control group. Regular curriculum in future early childhood education teachers include group work, role-playing and some contents directly and indirectly related to social and emotional competencies. Probably for this reason, participants in both groups improved their competencies and this intervention helped to increase some of them even further. Meta-analytic results show that similar programs effectively increase social and emotional competencies in different educational levels (Durlak et al., 2011). The current study showed that it is possible to increase these competencies in future teachers through innovations embedded in their curriculum. 
This study has several strengths and limitations. The "gold standard" methodology requires an intervention and a control group with random assignment of participants to each group (randomized controlled trials) (Murray, Farrington, \& Eisner, 2009). This study included an intervention and a control group but randomization of the participants was not possible. These groups were not totally equivalent, although they did not differ on the scores of any social and emotional competence (except one) at baseline and therefore can be considered similar. In addition, at the same time that the intervention is being implemented, students in both intervention and control groups are doing different courses so it is possible that the differences are not being directly caused by the SEL program. Larger samples are usually required to guarantee methodological quality (Farrington, Ttofi, \& Lösel, 2016), such as a minimum of 200 participants (Farrington \& Ttofi, 2009). In this study, the intervention group was relatively large but the control group was relatively small. High methodological quality also requires pre-test and post-test measures in both intervention and control groups (Farrington et al., 2016). These measures were taken in the current study. Nevertheless, a follow-up would have also been desirable but could not be conducted in this study. Thus, more research in needed to confirm the benefits of the program.

The results of this study have some important practical implications. Research showed that higher level of social and emotional competencies is related to school attentiveness in early childhood (Gormley, Phillips, Newmark, Welti, \& Adelstein, 2011) successful transition from high-school to university (Parker et al., 2006), prosocial behavior (Durlak et al. 2011), school success in early childhood (Zych et al., 2016) and academic achievement in adolescents (Mestre, Guil, Lopes, Salovey, \& Gil-Olarte, 2006), among other benefits. Thus, it would be desirable to include interventions similar to the one described in this article in all the programs for pre-service teacher education. New research with bigger sample sizes, follow ups and randomized control trials should be conducted to find the most effective components that could be included in future interventions designed and implemented to enhance social and emotional competencies in preservice and in-service teachers.

\section{Acknowledgement}

The current work was supported by a research grant for the project "E-Intelligence: risks and opportunities of the emotional competencies expressed online" (PSI2015-64114-R) granted to the first author and the research team by the Spanish Ministry of Economy and Competitiveness within the I+D+I 2015 National Program for Research Aimed at the Challenges of the Society (RETOS) and by University of Cordoba own Fostering Teaching Innovation Program.

\section{References}

Baguley, T. (2012). Serious stats: A guide to advanced statistics for the behavioral sciences. Palgrave: London.

Beck, A.T. (1988). Love is never enough: How couples can overcome misunderstandings, resolve conflicts, and solve relationship problems through cognitive therapy. New York: Harper \& Row. 
Brackett, M.A., Alster, B., Wolfe, C., Katulak, N., \& Fale, E. (2007). Creating an emotionally intelligent school district: A skill-based approach. In R. Bar-On, J. Jacobus, G. Maree \& M.J. Elias (Eds.), Educating people to be emotionally intelligent (pp.123-137). Wesport, CT: Praeager.

Barnett, W.S. (2010). Universal and targeted approaches to preschool education in the United States. International Journal of Child Care and Education Policy, 4, 1-12.

Burns, D.D. (1999). Feeling good: The new mood therapy (revised and updated). New York: HarperCollins Publishers.

Cabello, R., Ruiz-Aranda, D., \& Fernández-Berrocal, P. (2010). Docentes emocionalmente inteligentes. REIFOP, 13, 41-49.

Conners-Burrow, N. A., Patrick, T., Kyzer, A., \& McKelvey, L. (2017). A preliminary evaluation of REACH: Training early childhood teachers to support children's social and emotional development. Early Childhood Education Journal, 45, 187-199.

Darling-Churchill, K. E., \& Lippman, L. (2016). Early childhood social and emotional development: Advancing the field of measurement. Journal of Applied Developmental Psychology, 45, 1-7.

Denham, S. (2007). Dealing with feelings: how children negotiate the worlds of emotions and social relationships. Cognition, Brain, Behavior, 11, 1- 48 .

Domitrovich, C. E., Bradshaw, C. P., Berg, J. K., Pas, E. T., Becker, K. D., Musci, R., ... \& Ialongo, N. (2016). How do school-based prevention programs impact teachers? Findings from a randomized trial of an integrated classroom management and social-emotional program. Prevention Science, 17, 325-337.

Durlak, J.A., Weissberg, R.P., Dymnicki, A.B., Taylor, R.D., \& Schellinger, K.B. (2011). The impact of enhancing students' social and emotional learning: a meta-analysis of schoolbased universal interventions. Child Development, 82, 405-432.

Elbertson, N.A., Brackett, M.A., \& Weissberg, R.P. (2009). School-based social and emotional learning (SEL) programming: current perspectives. In A. Hargreaves, M. Fullan, D. Hopkins, \& A. Lieberman (Eds.), The second international handbook of educational change (pp. 1017-1032). Dordrecht: Springer.

Farrington, D.P. \& Ttofi. M.M. (2009). School-based programs to reduce bullying and victimization. Campbell Systematic Reviews, 9.

Farrington, D. P., Ttofi, M. M., \& Lösel, F. (2016). Developmental and social prevention. In D. Weisburd, D.P. Farrington, \& C. Gill (Eds.), What works in crime prevention and rehabilitation (pp. 15-75). New York: Springer.

Fernández-Berrocal, P., Extremera, N., \& Ramos, N. (2004). Validity and reliability of the Spanish modified version of the Trait Meta-mood Scale. Psychological Reports, 94, 751755.

Gormley, W.T., Phillips, D.A., Newmark, K., Welti, K., \& Adelstein, S. (2011). Socialemotional effects of early childhood education programs in Tulsa. Child Development, 82, 20952109.

Hamre, B. \& Pianta, R. (2001). Early teacher-child relationships and the trajectory of children's school outcomes through eighth grade. Child Development, 72, 625-638. 
Haymovitz, E., Houseal-Allport, P., Lee, R. S., \& Svistova, J. (2017). Exploring the Perceived Benefits and Limitations of a School-Based Social-Emotional Learning Program: A Concept Map Evaluation. Children \& Schools, 40, 45-54.

Jennings, P. A., Brown, J. L., Frank, J. L., Doyle, S., Oh, Y., Davis, R., ... \& Greenberg, M. T. (2017). Impacts of the CARE for Teachers program on teachers' social and emotional competence and classroom interactions. Journal of Educational Psychology, 109, 1010.

Jennings, P.A. \& Greenberg, M.T. (2009). The prosocial classroom: Teacher social and emotional competence in relation to student and classroom outcomes. Review of Educational Research, 79, 491-525.

Jones, M. S. \& Doolittle, E. J. (2017). Social and Emotional Learning: Introducing the Issue. The Future of Children, 27, 3-11.

Llorent, V. J., González-Gómez, A., Farrington, D. P. \& Zych, I. (2020). Social and emotional competencies and empathy as predictors of literacy competence. Psicothema. (in press)

Mahoney, J. L., Durlak, J. A., \& Weissberg, R. P. (2018). An update on social and emotional learning outcome research. Phi Delta Kappan, 100, 18-23.

Mestre, J. M., Guil, R., Lopes, P. N., Salovey, P., \& Gil-Olarte, P. (2006). Emotional intelligence and social and academic adaption to school. Psicothema, 18, 112-117.

Murray, J., Farrington, D. P., \& Eisner, M.P. (2009). Drawing conclusions about causes from systematic reviews of risk factors: the Cambridge quality checklists. Journal of Experimental Criminology, 5, 1-23.

Ortega, R., Romera, E.M., Mérida, R., \& Monks, C. (2009). Actividad e interacción entre iguales: Explorando el mapping como instrumento de observación en aulas de Educación Infantil. Infancia y Aprendizaje, 32, 405-420.

Palomera, R., Fernandez-Berrocal, P., Brackett, M.A. (2008). Emotional Intelligence as a Basic Competency in Pre-Service Teacher Training: Some Evidence. Electronic Journal of Research in Educational Psychology, 15, 437-454.

Parker, J.D.A., Hogan, M.J., Eastabrook, J.M., Oke, A., \& Wood, L.M. (2006). Emotional intelligence and student retention: Predicting the successful transition from high school to university. Personality and Individual Differences, 41, 1329- 1336.

Pons, F., Harris, P.L. \& de Rosnay, M. (2004). Emotion comprehension between 3 and 11 years: Developmental periods and hierarchical organization. European Journal of Developmental Psychology, 1, 127-152.

Poulou, M. S. (2017a). Social and emotional learning and teacher-student relationships: Preschool teachers' and students' perceptions. Early Childhood Education Journal, 45, 427-435.

Poulou, M. S. (2017b). Students' emotional and behavioral difficulties: the role of teachers' social and emotional learning and teacher-student relationships. The International Journal of Emotional Education, 9, 72 -89.

Salovey, P., Mayer, J.D., Goldman, S.L., Turvey, C., \& Palfai, T.P. (1995). Emotional attention, clarity, and repair: exploring emotional intelligence using the Trait Meta-Mood Scale. In J.W. Pennebaker (Ed.), Emotion, disclosure, \& health (pp. 125-151). Washington: American Psychological Association.

Schonert-Reichl, K. A. (2017). Social and emotional learning and teachers. The Future of Children, 27, 137-155. 
Schweinhart, L.J., Montie, J., Xiang, Z., Barnett, W.S., Belfield, C.R., \& Nores, M. (2005). Lifetime effects: The High/Scope Perry Preschool study through age 40. (Monographs of the High/Scope Educational Research Foundation, 14). Ypsilanti, MI: High/Scope Press.

Taylor, R. D., Oberle, E., Durlak, J. A., \& Weissberg, R. P. (2017). Promoting positive youth development through school-based social and emotional learning interventions: A meta-analysis of follow-up effects. Child Development, 88, 1156-1171.

Van Ryzin, M. J., \& Roseth, C. J. (2018). Cooperative learning in middle school: A means to improve peer relations and reduce victimization, bullying, and related outcomes. Journal of Educational Psychology, 110, 1192-1201.

Yang, W., Datu, J. A. D., Lin, X., Lau, M. M., \& Li, H. (2019). Can early childhood curriculum enhance social-emotional competence in low-income children? A meta-analysis of the educational effects. Early Education and Development, 30, 36-59.

Zych, I. (2010). SOS... Cómo recuperar el control de tu vida. Madrid: Pirmámide.

Zych, I. \& Farrington, D.P. (in press). Developmental preschool and school programs against violence and offending. In D.P. Farrington, L. Kazemian \& A.R. Piquero (Eds.) The Oxford Handbook on Developmental and Life-Course Criminology. Oxford, UK: Oxford University Press.

Zych, I., Ortega-Ruiz, R., Muñoz-Morales, R., \& Llorent, V.J. (2018) Dimensions and Psychometric Properties of the Social and Emotional Competencies Questionnaire (SECQ). Revista Latinoamericana de Psicología.

Zych, I., Ortega-Ruiz, R., \& Sibaja, S. (2016). Children's play and affective development: Affect, school adjustment and learning in preschoolers/El juego infantil y el desarrollo afectivo: Afecto, ajuste escolar y aprendizaje en la etapa preescolar. Infancia y Aprendizaje, 39, 380-400.

\section{Annex}

Details of the intervention

\section{Lesson 1. Introduction to social and emotional learning}

In this lesson, the concept of social and emotional learning was presented. Five components of the CASEL's model were explained and a video by Edutopia (https://www.youtube.com/watch?v=DqNn9qWoO1M) was shown. Benefits of enhancing social and emotional competencies in future pupils were explained. At the end of this lesson, students were asked to pay attention to their emotions and interpersonal interactions throughout the week and write down the most interesting examples.

\section{Lesson 2. Awareness of own emotions, thoughts and behaviors}

First, the leader of each team reviewed the homework and informed on the most common situations in which the team used social and emotional competencies, the most used competencies and the most difficult competencies according to each team. Then, the new lesson started. This lesson was based on the cognitive model developed by Beck (see, for example, Beck, 1988) according to which feelings depend on how each person interprets the 
reality and not on the reality itself. Examples were given by the teacher (e.g., The teacher asks me to go to her office and I feel anxious. Why do I feel anxious? - discussion - conclusion because of what I think about the situation and not because of the situation itself). Then, in small groups, students were asked to analyze situations in which they felt strong emotions, describe them in terms of situation - interpretation - consequences (emotions and behaviors), and generate other possible interpretations that would lead to different consequences. Examples were shared by the leaders and feedback from the teacher and the rest of the classmates was given. Homework consisted of writing down situations that generate strong emotions throughout the week in three columns (situation - interpretation - consequences).

\section{Lesson 3. Emotional management: looking for evidence}

First, groups reviewed the homework and leaders reported the most common and interesting situations, interpretations and consequences. They also analyzed and gave feedback on whether the interpretations were accurate given the situations. Feedback was given by the teacher and the rest of the classmates.

Afterwards, the teacher explained how to find evidence on whether an interpretation is accurate (again, based on cognitive model by Beck). Examples were given, such as, a thought "Jon stole a bicycle" could have evidence such as "I saw him... he told me he did that... he has a new bike that looks like the stolen one..." but not "he knows how to ride a bike... he has two legs so he can ride a bike...". Afterwards, examples of thoughts related to emotions such as "an airplane is going to crash" were given. Then, a two-column strategy for analyzing thoughts (one column for evidence against and one for evidence for the thought) was explained (see Zych, 2010 for more details). In small groups, students were asked to analyze one of the thoughts from their homework that was considered not accurate and produce an alternative interpretation (reported then by the leader). The homework was similar to the one from the lesson 2 but two new columns were added ("more accurate interpretation" and "change in emotion").

\section{Lesson 4. Emotional management: looking for evidence}

Given the complexity of the lesson 3 and difficulties expressed by the students, in this lesson, more examples of how to look for evidence regarding thoughts that generate emotions were given by the teacher. Afterwards, more examples were also analyzed by the students and the procedure and content from the lesson 3 was repeated.

\section{Lesson 5. Emotional management: cognitive distortions}

Homework was reviewed and the most interesting situations/interpretations/consequences were reported by the leaders. Groups also reviewed if members were able to change their interpretations when they were not accurate and if their emotions also changed. Feedback was given and then, the teacher explained the most common interpretation errors (cognitive distortions) according to cognitive models (Beck, 1988, Burns, 1999). Examples of distortions such as "all or nothing", "mind reading", "catastrophizing", "labeling" and "personalizing" 
were given by the teacher. Afterwards, students worked in small groups to identify these errors in their lesson 3 homework and change to more accurate interpretations. Examples were explained by the leaders and feedback was given by the teacher and classmates. Homework included a new column "cognitive distortion".

\section{Lesson 6. Self-esteem}

Homework was reviewed pointing out the most common interpretation errors, if they were changed to more rational thoughts and change in consequences. After receiving feedback from the teacher and classmates, the concept and importance of self-esteem was explained by the teacher. Self-talk examples were given by the teacher (with classroom discussion) and it was explained that people tend to "talk to themselves" in a way that is much crueler than when they talk to other people. For example, if a friend fails, they would usually tell them "do not worry, cheer up and you are going to do better next time" while it is common to say to oneself "I am a looser" about own failure. It was explained that criticizing and focusing on own behavior rather than the self is better for self-esteem (e.g., "I failed the exam" instead of "I am..."). It was also explained that it is important to focus on the positive side (what one already has and can improve or do instead of what is missing and wrong). Then, students were asked to write on papers one positive thing about themselves and one positive thing about each member of the small group (being specific e.g., he/she did... instead of he/she is nice...). All the papers were mixed and read anonymously. They were reviewed and shared with other classmates by the leaders. For the homework, each student was asked to write down three good things that they did every day.

\section{Lesson 7. Empathy}

Homework was reviewed and, "good things" were classified into categories (e.g., physical aspect, health, education, etc.) and reported by the leaders together with reflection on how people feel when they pay attention to their positive behaviors. After giving feedback, the teacher explained the concept of empathy (cognitive and affective) and its benefits. Active listening was also explained (listening and focusing on the other person, without judging, paraphrasing and response such as "aha", "I see", "I understand you"). Students worked in groups on an example of one situation in which one member of the team had a strong disagreement with somebody (after discussing different examples). This situation was written from the member's perspective and then, rewritten from the perspective of the other person explaining what they could have felt and why they could have been right. Reflection on how this situation could have been improved if there had been a high level of empathy was shared with the classmates and feedback was given. Homework consisted of self-registering disagreements throughout the week with three columns (the person with whom I disagree situation - how this person might be feeling and thinking).

\section{Lesson 8. The "I" messages}

Homework was reviewed and participants discussed and described people with whom they empathized and the most common situations. Thoughts and feelings attributed to other people 
and whether they were similar or different from one's own thoughts and feeling were also discussed. Then, the teacher explained that the "I" messages are a tool to achieve assertive communication in which people express their own desires, thoughts and feelings without attributing thoughts or feelings to others (e.g., "I'd like to have more active lifestyle" instead of "You are lazy"). On the other hand, others are asked about their own thoughts and feelings and they are listened to. Afterwards, in small groups, students worked on a conflict and were asked to give 10 reasons which would support their point of view using the "I" messages following the basic principle: "What I think is not better (or worse) than what you think". Examples were shared with the rest of the students through role-playings. For homework, participants were asked to identify conflicts throughout the week and write down three "I" messages that would support their point of view in each conflict.

\section{Lesson 9. Assertiveness}

First, students reviewed their homework in small groups pointing out the most common conflict, discussing similarities and differences among the members of the group and writing down three examples the best "I" messages in each team. These examples were shared with the rest of the classmates. Then, the teacher explained the concept of assertiveness (that one's own needs, decisions, feelings and thoughts are equally important as the needs, decisions, feelings and thoughts of other people). Examples of assertive rights were given (e.g., "You have the right to say no", "You have a right to ask for favors"). In small teams, students were asked to choose the assertive right that they consider the most important for their group. Then, they were asked to give five examples of real situations in their lives in which they needed this right explaining why they needed it and if they used it well. They were also asked to explain the outcome of these situations. Homework assignments consisted of writing down the situations in which each participant needed an assertive right throughout the week, describing the right and writing down if they used it in an adequate way together with the outcome of each situation.

\section{Lesson 10: Responsible decision making}

Homework was reviewed writing down the most common situations in each group, the most used assertive rights, if they were used adequately and the most common outcomes of the situations. Examples were shared with the rest of the classmates and feedback was given by students and by the teacher. Then, the teacher explained the importance of making decisions in a reflexive way and considering pros and cons of each possible option. In small teams, students were encouraged to find a situation in which they needed to make an important decision, find different options through brainstorming and then, to write down in two columns all the pros and cons of each option. They were also asked to assign weights to each pro/con according to its importance $(10-$ very important, $0-$ not important). They were asked to sum up the weights, analyze each column and suggest the best decision. For homework, participants were asked to make at least one decision throughout the week according to these instructions. Final 30 minutes were dedicated to review all the practical lessons, solve doubts and encourage students to continue to practice to improve their social and emotional competencies. 